TEA PAHIĆ

Sveučilište u Zagrebu, Učiteljski fakultet tea.pahic@gmail.com
Primljeno: 11. 04. 2019.

Prihvaćeno: 16. 10. 2019.

DOI: $10.21857 / \mathrm{y} 26 \mathrm{kec3dj9}$

\title{
UKLJUČENOST OČEVA U SKRB O DJECI U REGIJI SJEVEROZAPADNE HRVATSKE
}

Od današnjih se očeva očekuje da s majkom dijele različite aktivnosti vezane uz neposrednu skrb o djetetu kao i da ulažu sustavne napore za dobrobit djece jer njihova uključenost u odgoj predstavlja najvažniji aspekt očinstva za djecu, majke i njih same (Hawkins i Dollahite, 1997). Međutim, dok velik broj istraživanja u posljednjih tridesetak godina ukazuje na povećanje očeve funkcionalne uključenosti u skrb o djeci (Biller, 1993; Parke, 1996; Pleck, 1997; Clark \& O'Brien, 2004; Gray \& Anderson, 2012), očevi također vode brigu i o djetetovim društvenim, emocionalnim, kognitivnim i tjelesnim potrebama (Lamb, 1986; Palkovitz, 1997), aspektima očinstva koji su dosad vrlo slabo istraženi.

\section{UVOD}

Sukladno antropološkim nalazima, u prvim ljudskim, poligamnim, zajednicama prije nekoliko milijuna godina brigu za podizanje potomaka vodila je isključivo majka dok su očevi imali uglavnom zaštitničku funkciju (Gray i Anderson, 2012). Kako antropolozi smatraju, do promjena u obrascima skrbi za dijete dolazi s povećanjem ljudskog mozga, prije otprilike 150 tisuća godina. Za razliku od svojih predaka i drugih primata koji su se rađali sa setom vještina potrebnih za preživljavanje, ali s mnogo manjim kognitivnim kapacitetom, dijete Homo sapiensa u potpunosti je bilo ovisno o drugima te je, kako bi preživjelo, zahtijevalo 
dugoročnu intenzivnu skrb i njegu. Ljudsko se novorođenče nije bilo sposobno samostalno držati za majku, stalno ga se moralo nositi i trebalo mu je više njego nego što mu je sama majka mogla pružiti (Hrdy, 2009). Iz antropološke perspektive čini se da je upravo ova značajna evolucijska promjena dovela do potrebe da se u njegu djeteta uključe i drugi pripadnici zajednice: bake, ujne, tete, starije sestre i očevi. Ipak, smatra se da se očev povećani interes i sklonost ka direktnom uključenju u brigu o djetetu, a što predstavlja jednu od posebnih karakteristika ljudske vrste, mogao pojaviti tek s ustanovljavanjem dugotrajnih i monogamnih veza parova. Pretpostavka je da je razvojni plasticizam omogućio nastanak muškarčevih predispozicija za uključenost u skrb o djeci te tako stvorio novu okolinu koja je tijekom vremena dovela do promjena u funkcioniranju endokrinog sustava muškarca u smjeru razvoja očeve skrbi za dijete (Gray i Anderson, 2012). Nalazi različitih endokrinoloških i neuroznanstvenih istraživanja (npr., Fleming i sur., 2002; Kaitz, Shiri, Danziger, Hershko i Eidelman, 1994; Weisfeld, Czilli, Philips, Gall i Lichtman, 2003) pokazuju kako su očevi već od samog rođenja djeteta sposobni za stvaranje bliskih emocionalnih odnosa i veza s djetetom, kao i da su biološki spremni za poduzimanje ponašanja usmjerenih na zadovoljavanje djetetovih potreba što se dugo vremena smatralo ekskluzivnom majčinskom sposobnošću ili takozvanim majčinskim instinktom. Međutim, da bi očevi ostvarili takav odnos bliske povezanosti s vlastitim djetetom, neophodno je da se nalaze u djetetovoj neposrednoj blizini. Blizina im omogućava da vide, čuju i dodiruju dijete što izoštrava njihovu percepciju i poboljšava procjenu djetetovih reakcija u cilju adekvatnog i pravovremenog odgovaranja na djetetove potrebe. Drugim riječima, da bi očevi jednako kao i majke mogli stvoriti bliske odnose sa svojim djetetom neophodna je njihova direktna i pozitivna uključenost u brigu za dijete. $S$ druge strane, potrebno je istaknuti da očeva uključenost $u$ brigu za dijete nadilazi okvire njegove direktne uključenosti. Očevo investiranje, koje se u velikoj mjeri odnosi na očevu indirektnu uključenost u skrb o djeci, predstavlja ključnu komponentu mnogih modela ljudske evolucije. Iz evolucijske perspektive očevo je ulaganje u potomke u vidu pružanja materijalne sigurnosti ili zaštite poželjno jer povećava vjerojatnost preživljavanja te pomaže u stvaranju zadovoljavajućih uvjeta za rast i razvoj djeteta. Otac može investirati u dijete i bez da je fizički prisutan, na primjer kroz osiguranje sredstava za život i školovanje djeteta. Međutim, ključna je pretpostavka evolucijske teorije da je očeva motivacija za ulaganje u dijete vođena ponajprije očuvanjem pristupa reprodukcijskoj partnerici, a ne isključivo djetetovom dobrobiti. Kako navode Gray i Anderson (2012), žene preferiraju održavati odnose s muškarcima koji se brinu o djeci, a stupanj u kojem su muškarci spremni investirati u djecu može utjecati na njihov odnos. Očevo inve- 
stiranje u djecu evolucijski biolozi vide kao oportunitetni trošak: otac bi mogao investirati u nešto drugo, ali on zajedno s majkom djeteta ulaže u dijete radi djetetove dugoročne dobrobiti. U prilog ovoj pretpostavci govore i nalazi različitih socio-ekonomskih i psihologijskih istraživanja koji pokazuju da su u obiteljima u kojima su očevi visoko uključeni u skrb o djeci žene zadovoljnije i brakovi stabilniji (npr., Aldous, Mulligan i Bjarnason, 1998; Kalmijn, 1999), dok djeca uživaju dugoročne dobrobiti od očevog investiranja u vidu većeg zadovoljstva životom, boljeg obrazovanja i kasnijeg uspjeha u životu (npr., Amato, 1999; Čudina-Obradović i Obradović, 1995; Čudina-Obradović i Obradović, 2006; Flouri, 2005, Young i Roopnarine, 1994).

Stajališta antropologa i socijalnih psihologa razlikuju se od stajališta evolucijskih psihologa. Antropolozi i socijalni psiholozi pretpostavljaju da su vrsta i količina očeve uključenosti pod snažnim utjecajem dominantne kulture ili društva (Čudina-Obradović i Obradović, 2006; Hewlett, 2004). Kako navodi Hewlett (2004), kultura, u vidu ne-biološkog prijenosa znanja i prakse kroz generacije, snažno utječe na percepciju i doživljaj svijeta. Redovne interakcije pojedinaca koji imaju slične sheme doprinose oblikovanju takozvane emocionalne baze kulture pod čijim dojmom se ono što činimo i kako se ponašamo čini prirodnim i univerzalnim. Na primjer, u nekim je društvima zapadnjačke kulture danas sve uobičajenije da očevi aktivno sudjeluju pri rođenju djeteta. Međutim, različiti nalazi međukulturalnih i antropoloških istraživanja pokazuju da je ovakva praksa daleko od univerzalne i prirodne jer očevo sudjelovanje pri rođenju djeteta nije zabilježeno niti u jednoj dosadašnjoj kulturi (Hewlett i Hannon, 1989; prema Hewlett, 2004). Ipak, u društvima koja potiču i podržavaju očevo aktivno sudjelovanje pri porodu ova se praksa smatra važnim i prirodnim dijelom njegove očinske uloge.

Za razliku od evolucionista koji su u kontekstu očeve uključenosti u skrb o djeci usmjereni na istraživanja dugoročnih ishoda očinskog ulaganja u djecu, sociolozi su, kao i neki ekonomisti, uglavnom usmjereni na istraživanja raspodjele poslova u obitelji, uključujući i partnersku podjelu oko brige o djeci. Pregledom literature ustanovljena su četiri najčešća istraživačka modela: a) model relativnih ekonomskih resursa, b) strukturalni model ili model praktičnosti, c) model obiteljskih sustava i d) model rodne ideologije. Model relativnih ekonomskih resursa rodno je neutralan i počiva na principu da pojedinačni doprinos supružnika, u bilo kojem aspektu kućanstva, utječe na to kako će supružnici dijeliti teret kućanskih poslova (Kamo, 1988). Osnovna je pretpostavka ovog modela da očevi općenito više rade kako bi doprinijeli boljem ekonomskom statusu obitelji i zato zarađuju više od žena, a njihovo dulje izbivanje iz kuće zbog radnih obaveza vodi ka smanjenom angažmanu u obavljanju kućanskih poslova i brige o djeci (Cover- 
man, 1985). Međutim, nalaz Perrucci i sur. (1978; prema Kamo, 1998) govori da relativni prihod žene utječe na muževu uključenost samo ako supružnici dijele slične rodne stavove. Strukturalni model ili model praktičnosti također je rodno neutralan i polazi od pretpostavke da supružnici izvršavaju kućanske poslove, uključujući i brigu za dijete, ovisno o tome koliko vremena imaju na raspolaganju (Ishii-Kuntz i Coltrane, 1992). Prema tom modelu očevi su više uključeni ako je potrebna veća skrb, te ako su dostupni da tu skrb mogu i pružiti. Što je više djece u obitelji i što su djeca manja poslova u kućanstvu je više, stoga bi i očev doprinos trebao biti veći. U istraživanju Deutsch i sur. (1993) ovaj se model pokazao najprediktivnijim modelom očeve uključenosti u skrb o djeci u odnosu na ostale modele. I rezultati recentnije studije Wood i Repetti (2004) također potvrđuju da je broj majčinih sati provedenih na plaćenom poslu izvan kuće, kao i broj djece u obitelji, prediktivan za količinu očeve uključenosti u brigu o djeci sugerirajući pritom veću uključenost očeva što je više djece u obitelji i što su djeca mlađa. Model obiteljskih sustava temeljen je na pristupu teorije sustava koja sugerira da svaki član obitelji, odnos svakog člana s drugim članovima obitelji, te njihovi međusobni međuodnosi predstavljaju nezavisne podsustave unutar obitelji. Obiteljski podsustavi međusobno su povezani, a odnos supružnika, koji se odražava u bračnoj kvaliteti i dinamici, primarni je medijator očeve uključenosti (Aldous i sur., 1998). Očevi svojim odnosom prema majci mogu indirektno utjecati na odnos majke i djeteta, jednako kao što i majke svojim odnosom prema ocu mogu indirektno utjecati na odnos oca i djeteta (Parke, 2004). Sukladno ovom modelu očevi su više uključeni u skrb o djeci kada su interakcije između njih i njihovih partnerica pozitivne: kroz pozitivne interakcije očevi dobivaju osjećaj podrške u bavljenju djecom, poslom za koji se muškarci obično smatraju manje kompetentnim. Međutim, s obzirom da je za doživljaj bračne kvalitete važnija percepcija partnera o pravednosti raspodjele obaveza nego sama raspodjela (Perry-Jenkins i Folk, 1994), bračno zadovoljstvo, općenito uzevši, ne mora nužno predstavljati prediktor očeve uključenosti. Uz minimalnu uključenost očeva, ovisno o stavovima prema podjeli kućanskih obaveza i brige o djeci, parovi mogu imati percepciju pravednosti raspodjele poslova i iskazivati jednaku mjeru zadovoljstva brakom kao i parovi u kojima je očeva participacija visoka. Polazište modela rodne ideologije čini pretpostavka da rodne norme utječu na ljudska vjerovanja o prikladnosti obavljanja određenih poslova, odnosno, da su za podjelu poslova u kućanstvu i brige oko djeteta ključna vjerovanja partnera o tome koji su poslovi prikladni za muškarca, a koji za ženu. Općenito uzevši, na očeve se tradicionalno gleda kao na hranitelje obitelji koji su oslobođeni rada u kući, a njihov plaćeni posao izvan kuće i ambicija za napredovanjem ključni su za njihovu sliku o sebi (Hochhscild, 
1997; prema Aldous i sur., 1998), dok je briga o djeci tradicionalno ženski posao. Prema ovoj ideologiji tradicionalna podjela poslova posljedica je stavova stečenih rodnom socijalizacijom u djetinjstvu, ali i kasnije u životu osobe. Istraživački nalazi u okviru ovog modela nisu konzistentni. U nekim studijama stavovi očeva prema rodnim ulogama nisu povezani s njihovom uključenošću u brigu oko djece (na primjer, Barnett i Baruch, 1987; Coverman, 1985; Crouter, Perry-Jenkins, Huston i McHale, 1987), dok su u nekima očevi netradicionalni stavovi povezani s većom participacijom (na primjer, Deutsch i sur., 1993). Nedosljednost dobivenih istraživačkih rezultata objašnjavaju studije koje osim stavova očeva uzimaju u obzir i stavove majki prema rodnim ulogama. Nalazi ovih istraživanja pokazuju da tradicionalni stavovi majke, unatoč očevim netradicionalnim stavovima, mogu predstavljati barijeru njegovoj uključenosti. Do veće uključenosti oca neće doći ukoliko on za svoje postupke ne dobiva podršku od svoje partnerice (Fagan i Barnett, 2003; Pleck, 1997).

Iz psihologijske je perspektive uloga očeva tijekom vremena bila sustavno zanemarivana (Cabrera, Tamis-LeMonda, Bradley, Hoferth i Lamb, 2000; Carpenter, 2002; Wijnroks, 1999) i tek je pojava integrativnih modela roditeljstva tijekom 80-ih godina 20. stoljeća doprinijela većem osvještavanju uloge oca u obitelji kao i njegovoj važnosti u razvoju djeteta. Istraživanja u okviru pristupa koji uzima u obzir interakciju očeva, majki i djece započinju kasnih 70-ih godina 20. stoljeća, paralelno s istraživanjima utjecaja razvoda na dječji socio-emocionalni razvoj. Jedno od polazišta ovog pristupa činilo je redefiniranje uloge oca. Kao što je Marsiglio (1991; prema Marsiglio, 1995) zamijetio, najveći problem ranijih faza istraživanja očeve uključenosti predstavljala je povijesna percepcija uloge oca isključivo kao hranitelja obitelji i moralne podrške majci. Osnovnu karakteristiku ovog istraživačkog pristupa stoga čini upravo prepoznavanje da su očevi u skrb o djeci uključeni na različite načine i u različitim stupnjevima. Shodno tome, istraživanja u okviru ovog pristupa prvenstveno su usmjerena na aktivnosti koje očevi obavljaju s djecom i partnerom, kao i na ispitivanje povezanosti između različitih načina i količine očeve uključenosti s različitostima u dječjim karakteristikama i prilagodbi. Kako bi nadišli ograničenja ranijeg istraživačkog razdoblja u okviru ovog pristupa Lamb, Pleck, Charnov i Levine (1987; prema Lamb, 2000) razvijaju triparticijski model očeve uključenosti koji opisuje tri različite domene očeve uključenosti: njegovu direktnu uključenost, dostupnost i odgovornost. Prva domena, domena direktne uključenosti, odnosi se na direktne interakcije oca i djeteta za koje je karakteristična očeva puna posvećenost djetetu. Whiteside-Mansell i sur. (2001; prema Halme, Åsted-Kurki i Tarkka, 2009) sugeriraju da osnovnu pretpostavku očeve direktne uključenosti čine njegova emocionalna predanost i 
privrženost djetetu. Primjeri takve uključenosti su očeva igra s djetetom, hranjenje ili uspavljivanje djeteta i slično. Druga domena, domena dostupnosti, pretpostavlja očevu fizičku i psihološku dostupnost djetetu, pri čemu otac može, ali ne mora biti u direktnoj interakciji s djetetom. Na primjer, otac može gledati televiziju dok se dijete igra $u$ istoj ili susjednoj prostoriji, međutim on je dostupan, te je u slučaju da ga dijete pozove ili zatreba spreman odgovoriti na djetetove potrebe (Yeung i sur., 2001). Treća domena, domena odgovornosti, odnosi se na očev osjećaj odgovornosti za brigu o djetetu. Sukladno navodu McBride i Mills (1993) odgovornost se može očitovati kroz očevu uključenost u provođenju planiranja i dogovaranja aktivnosti koje se tiču dobrobiti djeteta, a koja također ne implicira njegovu direktnu interakciju s djetetom. Pleck i Stueve (2001; prema Kim, 2008) također tvrde da su očevi svjesni potreba svoje djece te da, shodno tome, poduzimaju potrebne korake kako bi zadovoljili njihove potrebe. Na primjer, očevi znaju kada dijete treba obaviti liječnički pregled stoga vode računa o tome. lako Lamb dimenziju odgovornosti smatra najvažnijom dimenzijom očeve uključenosti, nalazi mnogih studija sugeriraju da je uključenost očeva najmanja upravo na ovoj dimenziji (Lamb, 2000). Međutim, Palkovitz (1997) smatra kako prostor očeve uključenosti treba još više proširiti jer su očevi u život djece uključeni ne samo na funkcionalnoj razini, koju je iz perspektive istraživača najlakše mjeriti, već i na kognitivnoj i emocionalnoj razini, razinama koje je teže operacionalizirati jer nisu dostupne izravnom opažanju. Budući da se iz nalaza intervjua koje je proveo s očevima (Palkovitz, 1994; prema Palkovitz, 1997) pokazalo kako je velik dio njihovih dnevnih razmišljanja, procjena i planiranja vezano uz djecu, on sugerira proširenje konceptualizacije očeve uključenosti na kognitivnu i afektivnu dimenziju. Sukladno tome predlaže mjerenje uključenosti očeva kroz više različitih dimenzija: komunikaciju, poučavanje, nadzor, misaone procese, obavljanje zadataka za dijete, njegu, obavljanje kućanskih zadataka koji su vezani uz skrb o djetetu, zajedničke interese, dostupnost, planiranje, zajedničke aktivnosti, financijsku skrb, izražavanje osjećaja, zaštitu i emocionalnu podršku. Naglašava također da očevi, sukladno svojim preferencijama i karakteristikama djeteta, mogu biti više ili manje uključeni u određenim aspektima pri čemu uključenost $u$ jednoj domeni može, ali ne mora biti povezana s uključenošću u drugim domenama. Tako, na primjer, očevi mogu biti visoko uključeni u aktivnosti igre, a nisko u aktivnosti koje se tiču njege djeteta. Međutim, istovremeno mogu iskazivati velike napore da materijalno zbrinu dijete kroz planiranje i pribavljanje sredstava potrebnih za život i školovanje te biti visoko uključeni u nadzor djeteta, zbog čega bi ih se, gledano u cijelosti, trebalo smatrati jednako uključenima kao i majke. Najopćenitiji primjer indirektne uključenosti predstavlja očev prekovremeni 
rad. lako nakon rođenja djeteta velik broj očeva počinje raditi prekovremene sate kako bi za obitelj osigurali dodatna potrebna financijska sredstva, ovaj oblik uključenosti, kako smatraju Christiansen i Palkovitz (2001), često ne zadobiva priznanje u mjeri u kojoj to zaslužuje, kako u obitelji, tako i u suvremenoj literaturi o očinstvu. Palkovitz (1997) također sugerira da, iako neka mentalna zbivanja ne izgledaju kao oblik uključenosti, na primjer, određena razmišljanja, planovi, procjene i rješavanje problema u vezi djeteta, ova vrsta uključenosti može proizvesti posljedice koje će postati vidljive nakon nekog vremena. Na primjer, otac koji često radi prekovremeno može kroz razmišljanje o djetetu procijeniti kako je potrebno da provodi više vremena s njime te u skladu s vlastitim razmišljanjima reducirati broj radnih sati u korist vremena koje će provoditi s djetetom.

Kako u Hrvatskoj dosad postoji izuzetno mali broj istraživanja uključenosti očeva u skrb o djeci, a i ta postojeća se odnose isključivo na ispitivanje očeve funkcionalne uključenosti, provedenim se istraživanjem nastojalo ispitati u kojoj su mjeri očevi u regiji Sjeverozapadne Hrvatske uključeni u različite domene skrbi o djeci.

\section{CILJ ISTRAŽIVANJA}

Cilj provedenog istraživanja bio je ispitati očevu uključenost u skrb o djeci predškolske dobi kroz tri domene uključenosti prema operacionalizaciji Palkovitz (1997): funkcionalnu, emocionalnu i kognitivnu.

\section{Sudionici}

\section{Metoda}

U glavnom istraživanju sudjelovalo je 156 roditelja i njihove djece koja pohađaju neki od varaždinskih vrtića, a za potrebe ovog rada korišteni su samo rezultati anketa očeva. Od 156 očeva djece iz uzroka, njih 91,1\% žive u braku, a 8,3\% ih živi u izvanbračnoj zajednici. Prosječna dob očeva iz uzorka je 36,8 godina, a raspon dobi kreće se od 19 do 57 godina. Od ukupnog broja očeva iz uzorka njih 6 je imalo već jedan brak ranije, dok ih 5 ima djecu iz ranijeg braka pri čemu niti jedno od te djece ne živi s njima u sadašnjoj zajednici. Broj djece u obitelji kreće se od 1 do 4 pri čemu uzorak čine $56 \%$ obitelji s dvoje djece, $32 \%$ obitelji s jednim djetetom i $12 \%$ obitelji s više od dvoje djece.

\section{Postupak}

Provedeno istraživanje bilo je anketnog tipa, a roditelji su upitnike papir/ olovka ispunjavali u popodnevnim satima u prostorijama dječjih vrtića uz nazoč- 
nost istraživačice. Sama provedba ankete za roditelje odvijala se na način da su očevi i majke ispunjavali anketni upitnik koji se sastoji od 6 cjelina: a) opći sociodemografski podaci, b) ranija iskustva, zdravlje, posao i brak, c) obiteljski odnosi u djetinjstvu, d) uključenost oca u skrb o djetetu, e) stavovi prema očinstvu i f) osobine ličnosti: impulzivnost, avanturizam i empatija. Roditeljima je naglašena uputa da sve podatke u vezi djeteta daju isključivo za ciljno dijete, odnosno dijete koje je sudjelovalo u istraživanju. Potrebno vrijeme za ispunjavanje anketnog upitnika bilo je od 30-50 minuta, a roditelji su se u vezi bilo kakvih nejasnoća pri ispunjavanju upitnika mogli obratiti istraživačici. Ispunjavanjem upitnika u nazočnosti istraživačice također se nastojala osigurati dodatna kontrola kvalitete podataka.

Provedbi istraživanja pristupilo se nakon što je dobivena suglasnost od strane Ministarstva znanosti, obrazovanja i sporta te Etičkog povjerenstva Učiteljskog fakulteta Sveučilišta u Zagrebu. Istraživanje je provedeno u skladu s Etičkim kodeksom istraživanja s djecom te općim etičkim načelima dobrobiti sudionika i odgovornosti.

\section{Instrumenti i varijable}

\section{Funkcionalna uključenost oca}

Budući da zbog samog sadržaja čestica nije bilo prikladno formirati jednoznačnu skalu procjena za mjerenje očeve funkcionalne uključenosti korištene su tri skale: FU1, FU2 i FU3. Naime, za neke je aktivnosti vjerojatnije da se odvijaju na dnevnoj bazi ili čak više puta tijekom dana, dok je za druge to manje očekivano. Tako se, na primjer, dijete u vrtić vodi jednom dnevno, a pripremanje obroka za dijete može se provoditi više puta tijekom dana. Prva skala funkcionalne uključenosti, u našem istraživanju nazvana FU1, prikazana je u radu Dyer i sur. (2009) i sadrži 4 čestice koje ispituju očevu uključenost u njegu djeteta: hranjenje, vođenje djeteta na toalet, oblačenje i kupanje. Očevi su zamoljeni da procijene koliko su često uključeni u navedene aktivnosti s djetetom na skali: 0-nikada, 1-rijetko, 2-nekoliko puta mjesečno, 3-nekoliko puta tjedno, 4-otprilike jednom dnevno i 5-više nego jednom dnevno. Budući da, kako i Dyer i sur. (2009) sugeriraju, ovako definirane kategorije ne podrazumijevaju ekvidistantnost intervala, autori su, s ciljem poboljšanja mjernih karakteristika skale, proveli dodatno rekodiranje čestica. Oni su pošli od pretpostavke da su očevi, koji na skali od 0 do 5 izaberu da nešto čine otprilike jednom dnevno (4), 7 puta više uključeni od onih koji to ne čine nikada (0). Također, oni koji nešto rade više puta dnevno (5) najmanje su dva puta više uključeni od onih koji nešto rade otprilike jednom dnevno (4). 
Shodno tome konceptualna razlika u rezultatima na skali može biti veća nego što skala od 0 do 5 indicira i može predstavljati pogrešku mjerenja. Iz tog su razloga kategorije rekodirane na slijedeći način: $0=0 ; 1=0,5 ; 2=1 ; 3=4 ; 4=7$ i 5=14. Za potrebe obrade podataka u provedenom je istraživanju primijenjen identičan način rekodiranja. Ukupan rezultat u očeve funkcionalne uključenosti u njegu djeteta predstavlja suma rezultata svih čestica skale. Faktorskom se analizom po metodi glavnih komponenata ekstrahirala jedna komponenta s karakterističnim korijenom većim od 1 koja objašnjava 58,17\% varijance, a pouzdanost skale je dobra i iznosi $\alpha=, 838$.

Skala funkcionalne uključenosti FU2 konstruirana je za potrebe ovog istraživanja i sastoji se od 9 čestica za mjerenje očeve funkcionalne uključenosti u: uspavljivanje djeteta, čitanje ili pričanje priča djetetu, igre s loptom, društvene igre, šetnju s djetetom i odlazak na igralište, gledanje dječjih emisija ili crtića s djetetom, obavljanje kućanskih poslova i popravak uz prisutnost djeteta koje sudjeluje u toj aktivnosti (dijete „pomaže“ ocu), vođenje djeteta u vrtić i/ili kući iz vrtića, te vođenje djeteta na različite aktivnosti. Sve se procjene daju na skali od 0-nikada, 1-rijetko, 2-nekoliko puta mjesečno, 3- nekoliko puta tjedno i 4-gotovo svaki dan. Slijedeći logiku rekodiranja na skali FU1 vrijednosti procjena na skali FU2 rekodirane su na slijedeći način: $0=0 ; 1=0,5 ; 2=1 ; 3=4$ i 4=7. Ukupan rezultat čini suma rezultata na svim česticama skale. Faktorska analiza po metodi glavnih komponenata pokazala je da se jednom glavnom komponentom može objasniti $39,39 \%$ varijance očeve funkcionalne uključenosti na skali FU2, a koeficijent pouzdanosti iznosi $\alpha=, 787$.

Skalu FU3, za mjerenje uključenosti oca u neke povremene aktivnosti koje su vezane uz skrb o djetetu, čine dvije čestice: odlazak s djetetom na liječnički pregled i odlazak na sastanke u dječji vrtić. Svoju procjenu uključenosti u ovim aktivnostima očevi su davali na skali od 0-nikada, 1-rijetko, 2-često i 3-gotovo uvijek. lako se može prigovoriti valjanosti ovakve skale od dvije čestice, smatra se da ju je opravdano koristiti kao doprinos u kompozitnoj vrijednosti, zajedno $s$ ranije navedenim skalama. Koeficijent pouzdanosti je zadovoljavajući i iznosi $\alpha=, 630$. 
Tablica 1. Osnovni deskriptivni statistički pokazatelji skala FU1, FU2 i FU3 $(\mathrm{N}=156)$

\begin{tabular}{lcccccccccc}
\hline Skala & $\begin{array}{c}\text { Broj } \\
\text { čestica }\end{array}$ & Min & Max & $M$ & sd & $\alpha$ & $K-S$ & $p$ & $s$ & $k$ \\
\hline FU1 & 4 & 1 & 56 & 26,68 & 15,395 &, 838 &, 096 &, 000 &, 303 &,- 846 \\
FU2 & 9 & 4,5 & 63 & 32,33 & 13,638 &, 787 &, 050 &, 200 &, 083 &,- 550 \\
FU3 & 2 & 1 & 6 & 3,41 & 1,540 &, 630 &, 156 &, 000 &, 187 & $-1,040$ \\
\hline
\end{tabular}

\section{Emocionalna uključenost oca}

Emocionalna uključenost oca mjeri se skalom ekspresije emocionalnosti prema djetetu (EU1) i skalom koja se odnosi na očev doživljaj djetetovih emocija (EU2). Skala ekspresije emocionalnosti sastoji se od 5 čestica i konstruirana je za potrebe ovog istraživanja na temelju Palkovitz-ovog (1997) registra ponašanja iz domene afektivne uključenosti. Skala za ispitivanje očevog doživljaja dječjih emocija sastoji se od 4 čestice koje izvorno čine tek manji dio skale za ispitivanje roditeljskih metaemocija autorice Brajša-Žganec (1998). Faktor emocionalne ekspresije koji se ispituje skalom ekspresije emocionalnosti zapravo bi se mogao definirati kao ponašajno-emocionalni faktor koji može doći do izražaja samo u neposrednom kontaktu oca i djeteta. S druge strane, čestice za ispitivanje roditeljskih metaemocija ukazuju na način na koji očevi doživljavaju djetetove emocije, odnosno na njihovu, takoreći, indirektnu, kognitivno-emocionalnu uključenost. Skala emocionalne ekspresije prema djetetu sastoji se od 5 čestica, a očevi su procjenjivali koliko su često uključeni u navedene aktivnosti s djetetom: grljenje, ljubljenje, maženje, škakljanje i smijanje. Svoje su procjene davali na skali od 0 do 5, pri čemu 0 znači nikada, 1-rijetko, 2-nekoliko puta mjesečno, 3-nekoliko puta tjedno, 4-otprilike jednom dnevno i 5-više nego jednom dnevno. Ekstrakcijom faktora po metodi glavnih komponenata izlučen je jedan faktor $\mathrm{s}$ karakterističnim korijenom većim od 1 koji objašnjava 63,53\% varijance, a pouzdanost skale iznosi $\alpha=, 894$.

Skalu EU2 čine 4 čestice koje se odnose na očev doživljaj dječjih emocija (primjer čestice: Osjećaji mog djeteta jako utječu na mene), a očevi su zamoljeni da procijene svoje slaganje s navedenim tvrdnjama na skali od 0 do 5 , pri čemu: $0=$ uopće se ne odnosi na mene, $1=$ uglavnom se ne odnosi na mene, $2=$ niti se odnosi, niti se ne odnosi na mene, $3=$ odnosi se na mene i $4=$ odnosi se na mene u potpunosti. Primjer čestice na skali: Kada je moje dijete sretno i ja sam sretan radi njega. Ukupan rezultat na skali čini suma rezultata svih čestica. Faktorskom analizom po metodi glavnih komponenata ekstrahiran je jedan faktor s karakte- 
rističnim korijenom većim od 1 koji objašnjava 64,94\% varijance, a pouzdanost skale iznosi $\alpha=, 723$.

Tablica 2. Osnovni deskriptivni statistički pokazatelji za Skale emocionalne uključenosti EU1 i EU2 ( $\mathrm{N}=156)$

\begin{tabular}{ccccccccccc}
\hline Skala & $\begin{array}{c}\text { Broj } \\
\text { čestica } \\
\text { skale }\end{array}$ & Min & Max & $M$ & sd & $\alpha$ & $K-S$ & $p$ & $s$ & $k$ \\
\hline EU1 & 5 & 2,5 & 70,0 & 51,27 & 19,431 &, 894 &, 185 &, 000 &,- 783 &,- 446 \\
\hline EU2 & 4 & 6 & 16 & 10,83 & 1,472 &, 723 &, 267 &, 000 & $-1,221$ &, 675 \\
\hline
\end{tabular}

\section{Kognitivna uključenost oca}

Za potrebe mjerenja kognitivne uključenosti oca konstruirana je skala KU. Skala se sastoji od 12 čestica za mjerenje očevog kognitivnog angažmana u skrbi oko djeteta. Moglo bi se reći da varijable ove skale obuhvaćaju nekoliko aspekata skrbi pri čemu se kao dominantni faktori ističu: planiranje (primjer čestice: Planiram obiteljske izlete), preispitivanje roditeljskih odluka i postupaka (primjer čestice: Preispitujem sebe u vezi svojih postupaka prema djetetu), te razmišljanje o djetetu tijekom dana (primjer čestice: Razmišljam o svom djetetu kad radim neki posao). Očevi su bili zamoljeni da pored svake tvrdnje zaokruže broj koji ih najbolje opisuje pri čemu 0 označava nikada, 1-rijetko, 2-često i 3-gotovo uvijek. U namjeri utvrđivanja valjanosti skale za mjerenje očeve kognitivne uključenosti provedena je FA po metodi glavnih komponenata $s$ jednim zadanim faktorom. Izbacivanjem čestice Molim se za svoje dijete, čiji je početni ekstrahirani komunalitet bio nizak, postotak ukupno objašnjene zajedničke varijance faktora iznosi $41,38 \%$, a pouzdanost takve reducirane skale kognitivne uključenosti oca (11 čestica) iznosi $\alpha=$,852. U Tablici 8 prikazani su dobiveni rezultati svih čestica skale.

Tablica 3. Osnovni deskriptivni statistički pokazatelji Skale kognitivne uključenosti- KU ( $\mathrm{N}=156)$

\begin{tabular}{ccccccccccc}
\hline Skala & $\begin{array}{c}\text { Broj } \\
\text { čestica } \\
\text { skale }\end{array}$ & Min & Max & M & sd & $\alpha$ & K-S & $p$ & $s$ & $k$ \\
\hline KU & 11 & 4 & 33 & 23,08 & 5,492 &, 852 &, 060 &, 200 &,- 405 &, 186 \\
\hline
\end{tabular}




\section{Očeva motivacija za funkcionalnu uključenost}

Očeva motivacija za uključenost mjerena je za čestice funkcionalne uključenosti. Pored svake čestice kojom se ispituje funkcionalna uključenost očevi su dodatno trebali zaokružiti i razlog svoje najčešće uključenosti u navedenu aktivnost. Ponuđeni su im bili slijedeći odgovori: a) to najčešće radim zato jer sam to želim i b) to najčešće radim zato jer supruga nema vremena. Odgovor to najčešće radim zato jer sam to želim indicira da je otac intrinzično motiviran za navedenu aktivnost, dok odgovor to najčešće radim zato jer supruga nema vremena ukazuje na njegovu ekstrinzičnu motivaciju za navedenu aktivnost.

\section{REZULTATI I RASPRAVA}

Tablica 4. Postotak uključenosti očeva u njegu djeteta, igru s djetetom, dnevne obaveze i očeva motivacija ( $N=156)$

\begin{tabular}{|c|c|c|c|c|c|c|c|}
\hline Varijabla & Nikada & Rijetko & $\begin{array}{l}\text { Nekoliko } \\
\text { puta } \\
\text { mjesečno }\end{array}$ & $\begin{array}{l}\text { Nekoliko } \\
\text { puta } \\
\text { tjedno }\end{array}$ & $\begin{array}{c}\text { Jednom } \\
\text { dnevno } \\
\text { ili svaki dan }\end{array}$ & $\begin{array}{l}\text { Više nego } \\
\text { jednom } \\
\text { dnevno }\end{array}$ & $\begin{array}{c}\text { Činim to } \\
\text { zato jer } \\
\text { sam to } \\
\text { želim }\end{array}$ \\
\hline & $\%$ & $\%$ & $\%$ & $\%$ & $\%$ & $\%$ & $\%$ \\
\hline Hranjenje & 6 & 5,8 & 9,0 & 27,6 & 29,5 & 27,6 & 76,3 \\
\hline Toalet & 3,8 & 10,9 & 6,4 & 16,7 & 25,0 & 37,2 & 82,7 \\
\hline Oblačenje &, 6 & 8,3 & 9,0 & 22,4 & 35,9 & 23,7 & 80,1 \\
\hline $\begin{array}{l}\text { Kupanje, } \\
\text { umivanje }\end{array}$ & 1,9 & 12,8 & 14,1 & 38,5 & 19,9 & 12,8 & 80,1 \\
\hline Uspavljivanje & 1,9 & 17,3 & 12,8 & 44,2 & 23,7 & - & 85,9 \\
\hline $\begin{array}{l}\text { Čitanje ili } \\
\text { pričanje priča }\end{array}$ & 7,1 & 23,7 & 30,1 & 26,9 & 12,2 & - & 84,0 \\
\hline Igre s loptom &, 6 & 10,9 & 23,1 & 39,7 & 25,6 & - & 98,7 \\
\hline Društvene igre & 1,3 & 13,5 & 26,9 & 35,9 & 22,4 & - & 96,2 \\
\hline $\begin{array}{l}\text { Šetnja, odlazak } \\
\text { na igralište }\end{array}$ & 0 & 5,8 & 23,7 & 46,8 & 23,7 & - & 96,8 \\
\hline Gledanje crtića & 0 & 7,1 & 16,0 & 30,8 & 46,2 & - & 98,1 \\
\hline $\begin{array}{l}\text { Obavljanje } \\
\text { kućanskih } \\
\text { poslova i } \\
\text { popravaka s } \\
\text { djetetom }\end{array}$ & 6 & 10,3 & 28,2 & 37,8 & 23,1 & - & 96,2 \\
\hline $\begin{array}{l}\text { Vodim dijete u } \\
\text { vrtić }\end{array}$ & 1,9 & 10,3 & 12,2 & 22,4 & 53,2 & - & 77,6 \\
\hline $\begin{array}{l}\text { Vodim dijete } \\
\text { na različite } \\
\text { aktivnosti }\end{array}$ & 13,5 & 19,9 & 22,4 & 26,9 & 17,3 & - & 70,5 \\
\hline
\end{tabular}


Rezultati očeve uključenosti u njegu djeteta pokazuju da su očevi u aktivnosti koje se tiču neposredne njege djeteta uključeni uglavnom od nekoliko puta tjedno do jednom dnevno (Tablica 4). Najmanje su uključeni u aktivnosti oko kupanja i pranja djeteta, nekoliko puta tjedno, što je aktivnost koja se najvjerojatnije još uvijek smatra tipičnom majčinskom praksom. Ako pretpostavimo da su očevi koji su više nego jednom dnevno uključeni u aktivnosti hranjenja djeteta isti oni koji su više nego jednom dnevno uključeni u oblačenje, kupanje djeteta i vođenje djeteta na toalet, tada bismo mogli zaključiti da se postotak očeva iz uzorka koji svakodnevno obavljaju takozvanu majčinsku praksu kreće od 13\% do otprilike 25\%. Centar za edukaciju, savjetovanje i istraživanje-CESI (Bijelić, 2011) iz 2009. godine, u istraživanju na slučajnom uzorku stratificiranom prema dobi i geografskom području, provedenom u gradu Zagrebu te Osječko-baranjskoj i Vukovarsko-srijemskoj županiji, dobio je nalaze o znatno nižoj uključenosti očeva u neke aspekte brige o djeci do 5 godina starosti $(\mathrm{N}=160)$. Naime, njihovi nalazi govore da većina očeva samo ponekad priprema hranu djeci, dok ih oko $18 \%$ to radi svaki dan, u usporedbi s 57,1\% očeva iz našega uzorka koji izjavljuju da to rade svakodnevno (29,5\% jednom dnevno i $27,6 \%$ više nego jednom dnevno). S druge strane, istraživanje Tomić-Koludrović i Kunac (2000) provedeno 1999. godine na slučajnom uzorku od 3200 žena iz četiriju županija (Zagrebačke, Osječkobaranjske, Splitsko-dalmatinske i Istarske) koje su, između ostalog, procjenjivale uključenost svojih partnera u skrb o djeci, pokazalo je da je oko 32\% očeva uključeno u hranjenje djece u podjednakoj mjeri kao i majke. Iz navedenoga bismo neizravno mogli zaključiti da se radi o $32 \%$ očeva koji su u hranjenje djece uključeni svakodnevno. Nadalje, prema istraživanju CESI, u svakodnevno kupanje djece uključeno je $16,9 \%$ očeva, a u našemu uzorku $32,7 \%$, gotovo dvostruko više. Također, u svakodnevno mijenjanje pelena ili odjeće djetetu prema njihovim je nalazima uključeno $32,3 \%$ očeva, dok naši nalazi govore da $62,2 \%$ očeva svakodnevno mijenja pelene djetetu ili ga odvodi na toalet, a 59,6\% svakodnevno oblači dijete. Razlika je u rezultatima učestalosti očeve uključenosti, usporedbom između našega istraživanja i istraživanja CESI iz 2009. godine, evidentna, pri čemu je u našim nalazima postotak očeva koji su svakodnevno uključeni u aktivnosti oko djetetove njege gotovo dvostruko veći. S druge strane, rezultati istraživanja Tomić Koludrović i Kunac (2000) također govore o znatnoj većoj uključenosti očeva nego što to prikazuju nalazi CESI iz 2009. godine. Pitanje koje se ovdje postavlja jest predstavljaju li dobiveni nalazi našega istraživanja o većoj uključenosti očeva u njegu stvarni porast uključenosti očeva u odnosu na nalaze CESI od prije devet godina, ili se procjene očeva mogu pripisati nekim drugim faktorima, poput subjektivnosti procjene, davanju socijalno poželjnih odgovora, geografskoj regiji 
iz koje su ispitanici ili pak pristranosti uzorka. U spomenutome istraživanju CESI istraživači su na uzorku od 45 žena ispitali također i kako žene vide i procjenjuju angažman svojega partnera oko brige o djeci do 5 godina starosti. Svoju procjenu partnerovoga angažmana one su davale na istim česticama kao i njihovi partneri, a rezultati njihovih procjena prilično su ujednačeni što govori u prilog objektivnosti dobivenih nalaza procjena očeva. lako je kongruentnost procjena majki i očeva o očevoj uključenosti u brigu o djetetu potvrđena i drugim istraživanjima (na primjer, Aldous i sur., 1998; Barnett i Baruch, 1987), u ovom smo istraživanju, u cilju provjere objektivnosti mjerenja, također ispitali procjene majki o očevoj uključenosti u skrb o djetetu. Majke su očevu uključenost procjenjivale na svim česticama funkcionalne uključenosti, međutim, svoje su procjene davale na dihotomnoj skali: otac je rijetko/često uključen. Dobivene korelacije procjena majki o očevomu angažmanu s očevim procjenama uključenosti umjerene su, kreću se od ,30 za česticu prematanje / odvođenje djeteta na toalet do ,42 za česticu kupanje djeteta i značajne su na razini $p<, 001 .{ }^{1}$ Osim toga, dodatno smo provjerili povezanost očevih procjena i rezultata na skali socijalne poželjnosti. Korelacije očeve uključenosti za čestice koje se odnose na njegu djeteta i rezultata na skali socijalne poželjnosti nulte su ili niske, kreću se od -,00 do ,11 i nisu statistički značajne $(p>, 10)$. Iz navedenoga mogu se izvesti dva zaključka: prvo, procjene majki umjereno su povezane s procjenama očeva o uključenosti u skrb o djetetu i drugo, procjene očeva o uključenosti u njegu djeteta vjerojatno nisu odraz davanja socijalno poželjnih odgovora. Budući da istraživanja u svijetu pokazuju trend sve veće uključenosti očeva u skrb o djeci unatrag nekoliko desetljeća (Cabrera i sur., 2000; Lamb i Tamis-LeMonda, 2004; Parke, 1996; Yeung i sur., 2001; Young i Roopnarine, 1994, i drugi), skloni smo objašnjenju da je i u Hrvatskoj došlo do porasta uključenosti očeva u njegu djeteta tijekom posljednjeg desetljeća. Također, skloni smo vjerovati da porast očeve uključenosti najvjerojatnije nije tako velik kao što sugerira usporedba nalaza Tomić Koludrović i Kunac iz 1999. i CESI iz 2009. godine s nalazom našega istraživanja. Uzorak očeva iz ovog istraživanja nije slučajan, a i o razlozima zbog kojih su roditelji neke djece pristali, odnosno nisu pristali sudjelovati u našem istraživanju, možemo samo nagađati. Moguće je da neki očevi nisu dali pristanak za istraživanje upravo stoga što su vrlo malo uključeni u skrb o djetetu pa su zato i distribucije rezultata na svim skalama očeve uključenosti pomaknute prema višim vrijednostima.

1 Rezultati korelacija nisu prikazani jer se temelje na dodatnim analizama koje uključuju varijable koje nisu obuhvaćene ovim radom 
Rezultati na česticama koje se odnose na očevo obavljanje ostalih dnevnih obaveza s djetetom (Tablica 4) pokazuju da je 53,2\% očeva svakodnevno angažirano oko odvođenja djeteta u vrtić, dok su u obavljanje kućanskih poslova u nazočnosti djeteta, u vođenje djeteta na različite aktivnosti i uspavljivanje uglavnom uključeni nekoliko puta tjedno ili manje. Rezultati ranije spomenutoga istraživanja CESI, ali ovaj put na uzorku od N=537 muškaraca, u koji su uključeni i očevi s djecom koja su starija od 5 godina, govore da oko $65 \%$ očeva vodi svoje dijete u vrtić ili u školu, pri čemu je to isključiva obaveza očeva u $17,8 \%$ slučajeva, u 47,6\% slučajeva to je zajednička obaveza majki i očeva, a u 34,6\% slučajeva to je isključiva obaveza majke. Ovi nalazi zbog metodoloških razlika u pristupu i mjerenju nisu izravno usporedivi. Naime, u istraživanju CESI nije mjerena učestalost očeve uključenosti, međutim ovaj se podatak može u nekoj mjeri neizravno iščitati iz njihovih nalaza. Očevi koji su naveli da je odvođenje djeteta u vrtić isključivo njihova obaveza, to zasigurno rade svakodnevno. U obiteljima u kojima je to zajednička obaveza očeva i majki moguće je da majka odvodi dijete u vrtić, a otac dolazi po njega, ili obratno pa su tako oboje svakodnevno uključeni u ovu aktivnost. Ovako gledajući, prema nalazu istraživanja CESI, u svakodnevno bi odvođenje djeteta u vrtić i iz vrtića moglo biti uključeno oko $65 \%$ očeva. Međutim, budući da 34,6\% očeva iz njihova uzorka izjavljuje da to nikada ne radi, više je vjerojatno da neki očevi zajedničkom brigom smatraju i nešto što rade tek nekoliko puta mjesečno ili tjedno, što bi značilo da je postotak očeva koji su svakodnevno uključeni u odvođenje djeteta u vrtić vjerojatno ipak manji od $65 \%$. Bez obzira na to, iz navedenoga možemo izvesti zaključak da je aktivnost odvođenja djeteta u vrtić i iz vrtića (ili škole) vrlo česta kod očeva u Hrvatskoj. Korelacija procjena očeva i majki o očevoj uključenosti u skrb o djetetu u našemu je istraživanju najviša upravo za ovu česticu te iznosi $r=, 56$, uz $p<, 001$. S druge strane, najniža je korelacija procjena majki i očeva za česticu obavljanje kućanskih poslova uz djetetovu nazočnost, $r=, 22, p<, 05$. Ovakav nalaz može biti zanimljiv iz aspekta rodne ideologije jer može upućivati na činjenicu da su majke tradicionalnih stavova o ulogama majki i očeva manje zahtjevne što se tiče očeve uključenosti u kućanske poslove, stoga očevu uključenost procjenjuju češćom nego sami očevi. Ili obratno, majke egalitarnih stavova očekuju veću uključenost od svojih partnera zbog čega njihovu uključenost procjenjuju nižom pa je zato i korelacija između njihovih međusobnih procjena niža. Smatramo također važnim napomenuti da nalazi istraživanja CESI ne iznose podatak o tome postoji li razlika u uključenosti očeva u skrb o djetetu s obzirom na njihovo obrazovanje, a ni podatak o tome postoji li razlika u uključenosti očeva u brigu o djetetu između očeva iz Zagreba, Osječko-baranjske i Vukovarsko-srijemske županije. Ovakav 
podatak možda bi ukazao na različitu uključenost očeva ovisno o geografskom području ili obrazovanju, a naši bi se nalazi u tome slučaju možda više podudarali s rezultatom nekog od poduzorka koji bi bio bolji kriterij za usporedbu.

Rezultati na česticama koje mjere očevu uključenost u igru s djetetom (Tablica 4) variraju ovisno o vrsti aktivnosti, međutim postotak očeva koji su intrinzično motivirani za ove aktivnosti evidentno je veći u odnosu na aktivnosti koje se tiču njege i ostalih obaveza oko djeteta. Najveći postotak očeva, njih 46,2\% izjavljuje da svakodnevno gleda crtiće s djetetom, a u svakodnevno igranje društvenih igara, odlazak u šetnju ili na igralište te igre loptom uključeno je 20-25\% očeva. Postotak intrinzično motiviranih očeva najveći je upravo za ove aktivnosti (od 96-98\%). Rezultati istraživanja CESI iz 2009. godine na uzorku očeva s djecom do 5 godina starosti, na koje smo se već ranije referirali, pokazali su da je u igranje s djecom kod kuće svakodnevno uključeno $60,6 \%$ očeva, nekoliko puta tjedno $15 \%$, a rijetko ili nikad 3,8\% očeva. Nalazi istraživanja Tomić Koludrović i Kunac (2000) govore da očevi podjednako kao i majke sudjeluju u igri $(61,5 \%)$ i šetnji $(57,1 \%)$ s djetetom. lako ni ovi podaci nisu izravno usporedivi s našim podacima, vidimo da su očevi iz svih triju uzoraka uglavnom visoko uključeni u igranje s djetetom. Od svih navedenih aktivnosti u našemu je istraživanju najmanji broj očeva svakodnevno uključen u čitanje ili pričanje priča djetetu, a većina očeva izjavljuje da to radi nekoliko puta mjesečno ili nekoliko puta tjedno. Također, postotak očeva koji su intrinzično motivirani za ovu vrstu aktivnosti s djetetom nešto je niži i iznosi 84\%. Međutim, moramo zaključiti da je, gledamo li ove rezultate u cjelini, postotak očeva koji su kontinuirano uključeni u aktivnosti funkcionalne skrbi za dijete izrazito visok. Budući da smo u provedenome istraživanju mjerili učestalost, a ne vrijeme očeve uključenosti, ne možemo utvrditi da očevi provode više vremena u aktivnostima igre nego u funkcionalnoj skrbi za dijete kao što to pokazuju brojni nalazi iz literature (Craig, 2006; Gray i Anderson, 2012; Halme i sur., 2009; Lamb, 2000; McBride i Mills, 1993; Yeung i sur., 2001). Štoviše, čini se da su očevi iz našega uzorka svakodnevno gotovo podjednako uključeni u različite aktivnosti funkcionalne skrbi oko djeteta. Ovakav nalaz govori u prilog novijemu nalazu Schoppe-Sullivan, Kotila, Jia, Lang i Bower (2013) koji pokazuje da su očevi gotovo podjednako uključeni u aktivnosti njege, didaktičke i fizičke igre s djetetom. S druge strane, na temelju rezultata o motivaciji za određene aktivnosti ipak možemo zaključiti da veći broj očeva pokazuje intrinzičnu motivaciju za igru nego za aktivnosti vezane uz funkcionalnu skrb o djetetu.

Uključenost očeva u povremene obaveze u brizi o djetetu (Tablica 5) pokazuje da su očevi najmanje skloni odlascima na sastanke u dječji vrtić. Njih $16 \%$ nikada nije bilo na sastanku, $40 \%$ očeva rijetko odlazi, dok $44,6 \%$ njih često ili 
gotovo uvijek ide na sastanke u dječji vrtić. Postotak intrinzično motiviranih očeva za odlaske na sastanke u dječji vrtić najmanji je od svih i iznosi 60,9\%. Ni za odlazak s djetetom na liječnički pregled postotak intrinzično motiviranih očeva nije mnogo veći $(65,4 \%)$. Međutim, gledajući u cjelini, dobiveni postotak očeva koji izjavljuju da idu na sastanke u dječji vrtić i s djetetom na liječnički pregled zato što sami to žele, a ne zato što supruga/partnerica nema vremena, izuzetno je visok. Također, vidljivo je da $66 \%$ očeva izjavljuje da često ili gotovo uvijek odlazi s djetetom na liječnički pregled, dok tek $1,9 \%$ očeva to nikada nije učinilo. Navedeni podaci o očevoj motivaciji te o cjelokupnoj uključenosti u njegu i dnevne obaveze oko djeteta impliciraju ne samo da je veći broj očeva iz uzorka sklon egalitarnoj podjeli obaveza koje se tiču djeteta, već ukazuje i na njihov unutarnji osjećaj odgovornosti i brige za dijete. Ipak, u kontekstu generalizacije dobivenih nalaza, ove rezultate treba uzeti sa zadrškom. Švedsko je istraživanje iz 2010. godine na slučajnome uzorku od 237 očeva male djece iz županije Skåne pokazalo da je s djetetom na liječničkome pregledu barem jednom bilo otprilike $70 \%$ švedskih očeva, dok $38 \%$ njih to radi često ili redovito (Hallberg, Beckman i Håkansson, 2010). Ako uzmemo u obzir da je Švedska zemlja koja još od šezdesetih godina dvadesetog stoljeća brojnim programima socijalne politike potiče jednakost spolova u brizi za djecu, ovakav disparitet u dobivenim nalazima teško je objasniti.

Tablica 5. Učestalost uključenosti očeva u periodične obaveze (u postocima) $(\mathrm{N}=156)$

\begin{tabular}{lccccc}
\hline Varijabla & Nikada & Rijetko & Često & $\begin{array}{c}\text { Gotovo } \\
\text { uvijek }\end{array}$ & $\begin{array}{c}\text { Činim to zato } \\
\text { jer sam to } \\
\text { želim }\end{array}$ \\
\hline $\begin{array}{l}\text { Odlazak na sastanke u } \\
\text { dječji vrtić }\end{array}$ & 16,0 & 39,7 & 21,8 & 22,4 & $\%$ \\
$\begin{array}{l}\text { Odlazak s djetetom na } \\
\text { liječnički pregled }\end{array}$ & 1,9 & 32,1 & 39,7 & 26,3 & 65,4 \\
\hline
\end{tabular}

Nalazi očeve ekspresije emocionalnosti prema djetetu (Tablica 6) pokazuju da su očevi iz uzorka u velikoj mjeri skloni izražavanju pozitivnih emocija u kontaktu s djetetom. Naime, više od polovine očeva izjavljuje da svakodnevno više puta pokazuju djetetu izraze nježnosti kroz maženje, grljenje, ljubljenje i smijanje, i tek nešto manje njih kroz škakljanje, pri čemu ne postoje očevi koji izjavljuju da nikada ne izražavaju emocije prema djetetu na neki od navedenih načina. 
Iz sadržaja varijabli vidljivo je da navedena ponašanja uključuju izravne tjelesne kontakte koji djetetu pružaju osjećaj zaštite, voljenosti i prihvaćanja. Budući da ne postoji referentni okvir istraživačkih nalaza na koji bismo se mogli osvrnuti, jer nismo naišli na istraživanja koja izvještavaju o učestalosti navedenih pozitivnih interakcija između oca i djeteta, možemo samo konstatirati da je većina očeva iz našega uzorka izuzetno sklona izražavanju pozitivnih afekata prema djetetu.

Tablica 6. Očeva emocionalna uključenost - ekspresija emocionalnosti prema djetetu ( $\mathrm{N}=156)$

\begin{tabular}{lcccccc}
\hline Varijabla & Nikada & Rijetko & $\begin{array}{c}\text { Nekoliko } \\
\text { puta } \\
\text { mjesečno }\end{array}$ & $\begin{array}{c}\text { Nekoliko puta } \\
\text { tjedno }\end{array}$ & $\begin{array}{c}\text { Jednom } \\
\text { dnevno }\end{array}$ & $\begin{array}{c}\text { Više nego } \\
\text { jednom } \\
\text { dnevno }\end{array}$ \\
\hline Grljenje & $\%$ & $\%$ & $\%$ & $\%$ & $\%$ & $\%$ \\
Ljubljenje &, 0 & 2,6 & 3,8 & 9,0 & 21,8 & 62,8 \\
Maženje &, 0 & 5,5 & 4,5 & 8,3 & 25,6 & 57,1 \\
Škakljanje &, 0 & 2,6 & 7,1 & 20,5 & 21,8 & 48,1 \\
Smijanje &, 0 & 1,3 & 3,2 & 5,8 & 19,9 & 69,9 \\
\hline
\end{tabular}

Nalazi o očevom doživljaju dječjih emocija (Tablica 7) također ukazuju i na intenzivnu kognitivno-emocionalnu vezu očeva s djetetom. Većina očeva pokazuje veliku osjetljivost i za ugodne i za neugodne emocije svojega djeteta: sretni su kada je njihovo dijete sretno i teško im je kada je dijete žalosno, stoga su skloni brzo oprostiti djetetu kada ih razljuti. Ipak, iz raspona postignutih rezultata vidljivo je da postoje i očevi koji pokazuju nisku razinu osjetljivosti za djetetove emocije. Sukladno dobivenim pokazateljima mjere raspršenja oko prosječne vrijednosti možemo zaključiti da broj takvih očeva nije velik.

Tablica 7. Osnovni deskriptivni statistički pokazatelji distribucije rezultata na varijablama očeve emocionalne uključenosti - doživljaj dječjih emocija ( $N=156)$

\begin{tabular}{lccccc}
\hline \multicolumn{1}{c}{ Varijabla } & Min & Max & Raspon & M & sd \\
\hline $\begin{array}{l}\text { Kada je moje dijete sretno i ja } \\
\text { sam sretan radi njega }\end{array}$ & 1 & 4 & 3 & 3,76 &, 500 \\
$\begin{array}{l}\text { Osjećaji mog djeteta jako utječu } \\
\text { na mene }\end{array}$ & 1 & 4 & 3 & 3,57 &, 623 \\
$\begin{array}{l}\text { Ne mogu trpjeti da je moje dijete } \\
\text { žalosno }\end{array}$ & 1 & 4 & 3 & 3,51 &, 696 \\
$\begin{array}{l}\text { Ako me dijete razljuti ja mu vrlo } \\
\text { brzo oprostim }\end{array}$ & 1 & 4 & 3 & 3,38 &, 793 \\
\hline
\end{tabular}


Rezultati na varijablama koje mjere očevu kognitivnu uključenost (Tablica 8) ukazuju na općenito visoku razinu očeve kognitivne uključenosti u skrb o djetetu. Osim što većina očeva izjavljuje da često ili gotovo stalno razmišlja o djetetovoj budućnosti, u vidu planiranja djetetovoga školovanja i izdataka za njegovo školovanje, što očeva uloga iz tradicionalne uloge hranitelja obitelji i podrazumijeva, vidimo da su očevi gotovo $u$ istoj mjeri zaokupljeni i ostalim pitanjima djetetove dobrobiti koja nisu usko vezana uz njihovu instrumentalnu ulogu u skrbi za dijete. Naime, većina očeva iskazuje da često ili gotovo uvijek razmišlja o tome da ostane kod kuće s djetetom kada se dijete razboli (78\%). Ovaj je nalaz u velikome raskoraku s relativno recentnim nalazom Kokorić, Šimunić i Gregov (2013) na uzorku od 177 očeva iz različitih regija Republike Hrvatske i južne Hercegovine koji govori da svega $11 \%$ očeva razmišlja da ostane kod kuće s djetetom kada je dijete bolesno. ${ }^{2}$ Dobiveni disparitet u nalazima u određenoj se mjeri možda može pripisati sociodemografskim specifičnostima, međutim valja također istaknuti da istraživači u spomenutome istraživanju nisu uzeli u obzir djetetovu dob. Budući da je prosječna dob roditelja iz njihovoga uzorka 42 godine, a prosječna dob očeva iz našega uzorka 37 godina, možemo pretpostaviti da su i djeca na koju se referiraju očevi iz njihovoga uzorka također starija. Moguće je stoga da su neka djeca i srednjoškolske dobi pa možda roditelji ne trebaju ostajati kod kuće s njima kad su bolesni. Osim toga, treba napomenuti da je čak i istraživanje Tomić Koludrović i Kunac iz 2000. godine pokazalo da 22,2\% očeva podjednako kao i majke uzimaju bolovanje kada je dijete bolesno.

Nadalje, većina očeva iz uzorka ovog istraživanja izjavljuje da često ili gotovo uvijek razmišlja o svojemu djetetu kad radi neki posao, da planira vrijeme koje će provesti sa svojim djetetom kao način na koji će provoditi zajedničko slobodno vrijeme. Isto tako očevi iz uzorka pokazuju visoku razinu samorefleksije budući da većina njih iskazuje da često ili gotovo uvijek razmišlja o problemima svojega djeteta, usmjereni su na promišljanje o tome što bi mogli učiniti da njihovomu djetetu bude bolje, kao i na preispitivanje svojih postupaka i odluka u vezi s djetetom. Međutim, može se također uočiti kako postoje očevi koji nikada ne razmišljaju o nekome od ovih navedenih aspekata. Postotak ovih očeva izuzetno je nizak i kreće se od 1,3 do 9\% ovisno o sadržaju čestice, ako ne uzmemo u obzir česticu Molim se za svoje dijete, za koju pretpostavljamo da u ovom slučaju više odražava religijska ili vjerska uvjerenja od očeve kognitivne uključenosti. O planovima za školovanje djeteta nikada ne razmišlja 9\% očeva, a o izdacima za školovanje 7,7\%

Spomenuta čestica sastavni je dio mjernog instrumenta u istraživanju Kokorić i sur. (2013) te ovaj nalaz kao takav nije prikazan u objavljenome radu. Međutim, na zamolbu su autori rada omogućili uvid u originalne nalaze istraživanja. 
očeva. Kako bi se provjerilo da se ne radi o očevima niskog socioekonomskog statusa koji ne planiraju buduće školovanje i izdatke za školovanje djeteta zbog loše financijske situacije provedena je dodatnu korelacijska analizu između ovih čestica i očevih prihoda te ukupnih obiteljskih primanja. Dobiveni rezultati potvrđuju da ne postoji povezanost između primanja očeva i ukupnih obiteljskih primanja te planiranja budućega školovanja i izdataka za školovanje djeteta, a koeficijenti korelacije između ovih varijabla kreću se od $r=, 04$ do $r=, 08, p>, 05$. S druge strane, provjera povezanosti djetetove dobi i ovih varijabla pokazuje da je djetetova dob povezana s planiranjem školovanja i izdataka za djetetovo školovanje, pri čemu očevi starije djece češće planiraju djetetovo školovanje i izdatke za školovanje. Čini se stoga najvjerojatnijim objašnjenje da očevi koji ne planiraju djetetovo školovanje, a iskazuju uključenost u druge oblike planiranja i promišljanja o djetetu, smatraju kako je još prerano za razmišljanje o budućemu djetetovu školovanju.

Tablica 8. Očeva kognitivna uključenost (u postocima) $(N=156)$

\begin{tabular}{|c|c|c|c|c|}
\hline Varijabla & Nikada & Rijetko & Često & $\begin{array}{l}\text { Gotovo } \\
\text { uvijek }\end{array}$ \\
\hline & $\%$ & $\%$ & $\%$ & $\%$ \\
\hline $\begin{array}{l}\text { Razmišljam o svom djetetu kad radim } \\
\text { neki posao }\end{array}$ & 1,3 & 19,2 & 57,7 & 21,8 \\
\hline $\begin{array}{l}\text { Kad se moje dijete razboli, razmišljam } \\
\text { da ostanem kod kuće s njim }\end{array}$ & 1,3 & 20,5 & 39,7 & 38,5 \\
\hline $\begin{array}{l}\text { Planiram vrijeme koje ću provesti sa } \\
\text { svojim djetetom }\end{array}$ & 3,8 & 19,2 & 46,2 & 30,8 \\
\hline Planiram obiteljske izlete & 2,6 & 26,3 & 50,0 & 21,2 \\
\hline $\begin{array}{l}\text { Radim planove za školovanje svog } \\
\text { djeteta }\end{array}$ & 9,0 & 19,9 & 42,3 & 28,8 \\
\hline $\begin{array}{l}\text { Planiram izdatke za buduće } \\
\text { školovanje svog djeteta }\end{array}$ & 7,7 & 26,3 & 39,7 & 26,3 \\
\hline $\begin{array}{l}\text { Kad nisam sa svojim djetetom } \\
\text { zamišljam što ćemo raditi kad } \\
\text { budemo zajedno }\end{array}$ & 1,9 & 17,9 & 50,6 & 29,5 \\
\hline Molim se za svoje dijete & 21,8 & 24,4 & 30,1 & 23,7 \\
\hline $\begin{array}{l}\text { Razmišljam o problemima svog } \\
\text { djeteta }\end{array}$ & 1,3 & 10,9 & 51,3 & 36,5 \\
\hline $\begin{array}{l}\text { Razmišljam što bih mogao učiniti da } \\
\text { bi mojem djetetu bilo bolje }\end{array}$ & 0 & 3,8 & 36,5 & 59,6 \\
\hline $\begin{array}{l}\text { Preispitujem sebe u vezi svojih } \\
\text { postupaka prema svom djetetu }\end{array}$ & 3,8 & 16,7 & 37,8 & 41,7 \\
\hline $\begin{array}{l}\text { Preispitujem odluke koje sam donio u } \\
\text { vezi svog djeteta }\end{array}$ & 3,8 & 17,9 & 34,0 & 44,2 \\
\hline
\end{tabular}


lako je broj istraživanja koja se bave ispitivanjem očeve uključenosti u skrb o djeci, kao i dobrobiti koju djeca imaju od očeve pozitivne uključenosti, u svijetu posljednjih četrdesetak godina u stalnom porastu u Hrvatskoj je do sada objavIjen relativno mali broj istraživanja koja ispituju očev individualni doprinos u skrbi za dijete. Budući da provedeno istraživanje pruža nove i iscrpne informacije o uključenosti očeva u skrb o djeci ono predstavlja značajan doprinos hrvatskoj znanstvenoj literaturi na ovu temu. Usporedba dobivenih nalaza s nalazima postojećih domaćih istraživanja sugerira da očevi u različitim regijama Hrvatske nisu u podjednakoj mjeri uključeni u funkcionalnu skrb o djeci, dok za emocionalnu i kognitivnu domenu niti ne postoje podaci za usporedbu. Navedeno upućuje na potrebu provođenja daljnjih istraživanja očeve uključenosti u ostalim regijama Hrvatske te sukladno tome i razvoj programa za senzibiliziranje i educiranje javnosti o važnosti uključenosti očeva u skrb o djeci predškolske dobi.

\section{ZAKLJUČAK}

Rezultati provedenog istraživanja pokazuju da je uključenost očeva iz uzorka u funkcionalnu, emocionalnu i kognitivnu skrb o djetetu izuzetno visoka. Nalazi o uključenosti u funkcionalnu skrb pokazuju da su očevi gotovo podjednako uključeni u sve domene funkcionalne skrbi: njegu, igru, dnevne i povremene obaveze oko djeteta, kao i da su uglavnom intrinzično motivirani za obavljanje ovih aktivnosti. lako je postotak intrinzično motiviranih očeva u svim aspektima funkcionalne skrbi izuzetno visok, očevi su više intrinzično motivirani za igru s djetetom nego za ostale oblike funkcionalne skrbi. Na temelju nalaza koji se odnose na očevu emocionalnu uključenost može se konstatirati da je većina očeva izuzetno sklona izražavanju pozitivnih afekata u odnosu s djetetom kao i da većina očeva iskazuje veliku osjetljivost za djetetove emocije. Rezultati na česticama skale kognitivne uključenosti potvrđuju da očevi svakodnevno razmišljaju o različitim pitanjima djetetove dobrobiti, a ne samo o pitanjima koja su usko vezana uz njihovu instrumentalnu ulogu u skrbi za dijete.

\section{LITERATURA}

1/ J. ALDOUS, G. M. MULLIGAN, i T. BJARNASON (1998). Fathering over Time: What Makes the Difference? Journal of Marriage and Family, 60(4), 809820.

2/ P. R. AMATO, i F. RIVERA (1999). Paternal Involvement and Children's Behavior Problems. Journal of Marriage and the Family, 61(2), 375-384.

3/ R. C. BARNETT i G. K. BARUCH (1987). Determinants of Fathers' Participation in Family Work. Journal of Marriage and the Family, 49, 29-40. 
4/ N. BIJELIĆ (2011). Muškarci i rodna ravnopravnost u Hrvatskoj: Rezultati istraživanja IMAGES - International Men and Gender Equality Survey. Zagreb: Centar za edukaciju, savjetovanje i istraživanje.

5/ H. B. BILLER (1993). Fathers and Families: Paternal Factors in Child Development. Conneticut: Auburn House.

6/ N. J. CABRERA, C. S. TAMIS-LEMONDA, R. H. BRADLEY, S. HOFERTH i M. LAMB (2000). Fatherhood in the Twenty-First Century. Child Development, 71(1), 127-136.

7/ B. CARPENTER (2002). Inside the Portrait of the Family. Early Child Development and Care, 172(2), 195-202.

8/ S. L. CHRISTIANSEN i R. PALKOVITZ (2001). Why the "Good Provider" Role Still Matters: Providing as a Form of Paternal Involvement. Journal of Family Issues, 22(1), 84-106.

9/ L. CLARKE i M. O'BRIEN (2004). Father Involvement in Britain; The Research and Policy Evidence. (Ur.) R. D. DAY i M. E. LAMB, Conceptualizing and Measuring Father Involvement. New Jersej: LEA.

10/ S. COVERMAN (1985). Explaining Husbants' Participation in Domestic Labor. The Sociological Quarterly, 26(1), 81-97.

11/ L. CRAIG (2006). Does Father Care Mean Fathers Share? A Comparison of How Mothers and Fathers in Intact Families Spend Time With Children. Gender \& Society, 20(2), 259-281.

12/ A. C. CROUTER, M. PERRY-JENKINS, T. L. HUSTON i S.M. McHALE (1987). Processes Underlying Father Involvement in Dual-Earner and Single-Earner Families. Developmental Psychology, 23(3), 431-440.

13/ M. ČUDINA-OBRADOVIĆ i J. OBRADOVIĆ (1995). Utjecaj bračnog emocionalnog sklada roditelja na školski uspjeh i ponašanje djece. Društvena istraživanja, 18-19(4-5), 627-639.

14/ M. ČUDINA-OBRADOVIĆ i J. OBRADOVIĆ (2006). Psihologija braka i obitelji. Jastrebarsko: Naklada Slap.

15/ F. M. DEUTSCH, J.B. LUSSIER i L. J. SERVIS (1993). Husbands at Home: Predictors of Paternal Participation in Childcare and Housework. Journal of Personality and Social Psychology, 65(6), 1154-1166.

16/ W. J. DYER, B. A. McBRIDE, R. MILAGROS SANTOS i L. M. JEANS (2009). A Longitudinal Examination of Father Involvement With Children With Developmental Delays: Does Timing of Diagnosis Matter? Journal of Early Intervention, 31(3), 265-7-281.

17/ J. FAGAN i M. BARNETT (2003). The Relationship Between Maternal Gatekeeping, Paternal Competence, Mothers' Attitudes About the Father Role, and Father Involvement. Journal of Family Issues, 24(8), 1020-1043. 
18/ A. S. FLEMING, C. CORTER, J. STALLINGS i M. STEINER (2002). Testosterone and Prolactin are Associated with Emotional Responses to Infant Cries in New Fathers. Hormones and Behavior, 42, 399-413.

19/ E. FLOURI (2005). Fathering and Child Outcomes. Chichester: John Wiley \& Sons.

20/ P. B. GRAY i K. G. ANDERSON (2012). Fatherhood: Evolution and Human Paternal Behavior. Cambridge, MA: Harvard University Press.

21/ A. C. HALLBERG, A. BECKMAN i A. HÅKANSSON (2010). Many Fathers Visit the Child Health Care Centre, but Few Take Part in Parents' Groups. Journal of Child Health Care, 14(3), 296-303.

22/ N. HALME, P. ÅSTEDT-KURKI, i M.T. TARKKA (2009). Fathers' Involvement with Their Preschool-age Children: How Fathers Spend Time with Their Children in Different Family Structures. Child Youth Care Forum, 38, 103-119.

23/ A. J. HAWKINS i D. C. DOLLAHITE (1997). Beyond the Role-Inadequacy Perspective of Fathering. U A. J.Hawkins i D. C. Dollahite (ur.), Generative fathering: Beyond deficit perspectives. Thousand Oaks, CA: Sage.

24/ B. S. HEWLETT (2004). Fathers in Forager, Farmer, and Pastoral Cultures. (Ur.) M. E. LAMB, The Role of the Father. Chichester: Wiley.

25/ S. HRDY (2009). Mothers and Others: The Evolutionary Origins of Mutual Understanding. Cambridge: Harvard University Press.

26/ M. ISHII-KUNTZ i S. COLTRANE (1992). Predicting the Sharing of Household Labor: Are Parenting and Housework Distinct? Sociological Perspectives, 35(4), 629-647.

27/ M. KAITZ, S. SHIRI, S. DANZIGER, Z. HERSHKO i A. I. EIDELMAN (1994). Fathers Can Also Recognize Their Newborns by Touch. Infant Behavior and Development, 17, 205-207.

28/ M. KALMIJN (1999). Father Involvement in Childrearing and the Perceived Stability of Marriage. Journal of Marriage and Family, 61(2), 409-421.

29/ Y. KAMO (1988). Determinants of Houshold Division of Labor: Resources, Power, and Ideology. Journal of Family Issues, 9(2), 177-200.

30/ K. K. KIM (2008). The impact of fathers' involvement and parenting styles on their Children's social competence: a study of korean fathers in the United states. (A Dissertation Submitted to the Graduate Faculty of The University of Georgia in Partial Fulfillment of the Requirements for the Degree Doctor of Phylosophy). Georgia: Athens. Dostupno na web stranici: https://getd.libs. uga.edu/pdfs/kim_keun-kyu_200808_phd.pdf (01.03.2018.)

31/ M. KOKORIĆ, A. ŠIMUNIĆ i Lj. GREGOV (2013). Stav o bračnim ulogama i percepcija obiteljskih odnosa kod zaposlenih supružnika. Revija za socijalnu politiku 21(1), 1-17. 
32/ M. E. LAMB (1986). The Changing Role of Fathers. (Ur.) M. E. LAMB, The Father's Role: An Applied Perspective. New York: John Wiley.

33/ M. E. LAMB (2000). The History of Research on Father Involvement: An Overview. Marriage \& F amily Review, 29(2-3), 23-42.

34/ M. E. LAMB i C. S. TAMIS-LEMONDA (2004). The Role of the Father. (Ur.) M. E. LAMB, The Role of the Father. Chichester: Wiley.

35/ W. MARSIGLIO (1995). Fathers'Diverse Life Course Patterns and Roles: Theory and Social Interventions. (Ur.) W. MARSIGLIO, Fatherhood: Contemporary theory, research, and social policy. Thousand Oaks, CA: Sage.

36/ B. A. McBRIDE i G. MILLS (1993). A Comparison of Mother and Father Involvement With Their Preschool Age Children. Early Childhood Research Quarterly, 8, 457-477.

37/ R. PALKOVITZ (1997). Reconstructing „Involvement“: Expanding Conceptualizations of Men's Caring in Contemporary Families. (Ur.) A. J. HAWKINS i D. C. DOLLAHITE, Generative Fathering: Beyond Deficit Perspectives. Thousand Oaks, CA:Sage.

38/ R. D. PARKE (1996). Fatherhood. Cambridge, MA: Harvard University Press.

39/ R. D. PARKE (2004). Development in the Family. Annual Reviews of Psychology, 55, 365-399.

40/ M. PERRY-JENKINS i K. FOLK (1994). Class, Couples, and Conflict: Effects of the Division of Labor on Assessments of Marriage in Dual-Earner Families. Journal of Marriage and Family, 56(1), 165-180.

41/ J. H. PLECK (1997). Paternal Involvement: Levels, Sources and Consequences. (Ur.) M. E. LAMB, The Role of the Father in Child Development. New York: John Willey.

42/ S. J. SCHOPPE-SULLIVAN, L. KOTILA, R. JIA, S. N. LANG i D. J. (2013). Comparisons of Levels and Predictors of Mothers' and Fathers' Engagement with their Preschool Aged Children. Early Child Development and Care, 183(3-4), 498-514.

43/ G. E. WEISFELD, T. CZILLI, K. A. PHILIPS, J. A. GALL i C. M. LICHTMAN (2003). Possible Olafaction-Based Mechanisms in Human Kin Recognition and Inbreeding Avoidance. Journal of Experimental Child Psychology, 85, 279295.

44/ L. WIJNROKS (1999). Book Review: Fatherhood. The Developing Child Series. International Journal of Behavioral Development, 23(1), 281-284. https:// doi.org/10.1177/016502549902300116

45/ J. WOOD i R. REPETTI (2004). What gets dad involved? A Longitudinal Study of Change in Parental Caregiving Involvement. Journal of Family Psychology, $18,237-249$. 
46/ W. J. YEUNG, J. F. SANDBERG, P. E. DAVIS-KEAN i S. L. HOFFERTH (2001). Children's Time with Fathers in Intact Families. Journal of Marriage and Family, 63, 136-154.

47/ D. M. YOUNG i J. L. ROOPNARINE (1994). Fathers' Childcare Involvement With Children With and Without Disabilities. Topics in Early Childhood Special Education, 14(4), 488-502.

\section{SAŽETAK \\ UKLJUČENOST OČEVA U SKRB O DJECI U REGIJI SJEVEROZAPADNE HRVATSKE}

Zbog povijesne percepcije uloge oca isključivo kao hranitelja obitelji i moralne podrške majci, uloga oca u životu djeteta nije se sustavno istraživala sve do 80-ih godina 20. stoljeća. Do osvještavanja važnosti istraživanja ovog zanemarenog područja dovelo je prepoznavanje da su očevi u skrb o djeci uključeni u različitim stupnjevima i na različite načine, kao i da su način i količina očeve uključenosti u skrb o djeci povezani s razvojem dječjih sposobnosti i socio-emocionalnom prilagodbom. U posljednjih tridesetak godina u svijetu je proveden velik broj istraživanja iz ove domene, a rezultati ukazuju na sustavno povećanje očeve funkcionalne uključenosti u skrb o djetetu tijekom vremena (Biller, 1993; Parke, 1996; Pleck, 1997; Clark \& O’Brien, 2004; Gray \& Anderson, 2012). Međutim, Palkovitz je još 1997. godine predložio proširenje koncepta očeve uključenosti budući da su očevi u život djece uključeni ne samo na funkcionalnoj, već i na afektivnoj i kognitivnoj razini. Svojim ponašanjima oni djeci pružaju osjećaj sigurnosti i voljenosti, a svjesni su i djetetovih društvenih, emocionalnih, kognitivnih i tjelesnih potreba, te svjesno planiraju strategije za njihovo zadovoljavanje. $\mathrm{S}$ obzirom na navedeno ovim se istraživanjem nastojalo utvrditi u kojoj su mjeri očevi u regiji sjeverozapadne Hrvatske $(N=156)$ uključeni u različite aspekte skrbi o predškolskoj djeci: funkcionalni aspekt, koji je na području naše zemlje tek djelomično istražen, ali i emocionalni i kognitivni, aspekte koji su i u globalnim razmjerima nedostatno istraženi. Provedeno je istraživanje anketnog tipa, a očevi su na skalama funkcionalne, emocionalne i kognitivne uključenosti u skrb o djetetu davali svoje procjene o uključenosti. Rezultati provedenog istraživanja pokazuju da su očevi visoko uključeni u sve tri domene skrbi o djetetu. U domeni funkcionalne uključenosti očevi su podjednako uključeni u njegu, igru, dnevne i povremene obaveze oko djeteta te su u velikoj mjeri intrinzično motivirani za obavljanje ovih aktivnosti. Također, većina je očeva izuzetno sklona izražavanju 
pozitivnih afekata u odnosu s djetetom, iskazuje veliku osjetljivost za djetetove emocije, svakodnevno razmišlja o različitim pitanjima djetetove dobrobiti i planira strategije za njihovo ostvarivanje.

Ključne riječi: očevi; predškolska djeca; funkcionalna uključenost; emocionalna uključenost; kognitivna uključenost.

\section{SUMMARY \\ FATHERS' INVOLVEMENT IN CHILD CARE IN THE REGION OF NORTHWESTERN CROATIA}

Due to the historical perception of the father's role solely as family breadwinner and moral support to the mother the role of the father in the child's life has not been systematically researched until the 80 's of the 20th century. The recognition that fathers are involved with children in varying degrees and in different ways, and that the way and the amount of their involvement in child care are linked with children's cognitive abilities and socio-emotional adjustment, has led to the recognition of the importance of the research in that domain. Many researches have been conducted in this domain in the past thirty years, and the results indicate a systematic increase of the father's functional involvement in child care over time (Biller, 1993; Parke, 1996; Pleck, 1997; Clark \& O'Brien, 2004; Gray \& Anderson, 2012). However, in 1997 Palkovitz proposed extending the concept of fathers' involvement, as fathers in the life of their children are involved not only across the functional, but also across the affective and cognitive level. Through their behavior fathers provide a sense of security and love to children, and they are aware of the child's social, emotional, cognitive and physical needs, and knowingly plan strategies for their satisfaction. Considering the above mentioned, the aim of conducted research was to determine the extent to which fathers in Northwestern Croatia $(\mathrm{N}=156)$ are involved in different aspects of care for preschool children: the functional aspect, which is only partially researched in Croatia, but also emotional and cognitive aspects which are poorly represented on a global scale research. Fathers provided their estimates on scales of functional, emotional and cognitive involvement. Research results show that fathers are highly involved in all three domains of child care. In the domain of functional involvement fathers are equally involved in care, play, daily and occasional childcare obligations and are largely intrinsically motivated to perform these activities. Also, most fathers are extremely prone to express- 
ing positive emotions in relationship with the child, express great sensitivity to the child's emotions, think about the various issues of child welfare on a regular basis and plan strategies for their realization.

Key Words: fathers; preschool children; functional involvement; emotional involvement; cognitive involvement. 
